\title{
研究室紹介
}

\section{金沢大学 環日本海域環境研究センター 臨海実験施設}

関口 俊男 (金沢大学 環日本海域環境研究センター 臨海実験施設・助教) E-mail: t-sekiguchi@se.kanazawa-u.ac.jp

\section{はじめに}

金沢大学環日本海域環境研究センター臨海実験施設は、 本学のある金沢市からは、およそ130 km 離れている石川 県能登町小木にあります。当施設は、能登半島の富山湾 側 (内浦) の中央やや北寄りに位置している九十九湾に面 しています。九十九湾は、湾口の幅がおよそ200 m、最 大奥行き $1,200 \mathrm{~m}$, 水深 $25 \mathrm{~m}$ の典型的な溺れ谷で、荒天で も湾内は穏やかで波浪がほとんどありません。施設の周 辺は国定公園に、湾口は海中公園に指定されています。 九十九湾の生物相は、日本海を北上する対馬暖流の支流 と富山湾の固有冷水域の影響を受け、南方系と北方系の 種が観察できます。このように、豊かな自然に囲まれた 九十九湾は、海洋生物の研究や教育に適した場所だとい えます。

\section{臨海実験施設の構成員}

現在、当施設は教員スタッフ4名、技術スタッフ2名、 事務スタッフ1名の計7名で運営されています。また学生 は、修士2名、学士2名 (平成30年4月現在) が在籍してい ます。教員スタッフは、施設長の鈴木信雄教授、木谷洋 一郎助教、亀井宏泰助教、そして関口となっています。 亀井助教は平成 28 年 2 月、木谷助教は平成 28 年 3 月に着任 しました。鈴木教授、木谷助教、関口の3名は、環日本 海域研究センター所属であり、準専任教員として理工研 究域の自然システム学類の教育に携わっています。一方、 亀井助教は、理工学域自然システム学類の専任教員です。 教員スタッフは、それぞれ個別のラボを主宰しており学 生も各ラボ所属になっております。各教員の交流は盛ん で、実験施設を共有し、共著論文も多数あります。

\section{臨海実験施設での研究}

臨海実験施設の研究は、教員の数だけ多彩です。鈴木 教授は、キンギョやメジナなどのウロコの培養系を用い て、カルシウム代謝の研究を行なっています。このウロ コの培養系を活用し、種々のホルモンやその誘導体、多 環芳香族炭化水素類や重金属といった環境污染物質、さ らに微小重力や超音波などの物理的刺激のカルシウム代 謝に及ぼす影響を調べています。木谷助教は、魚類の体 表粘液や血液に存在する抗菌タンパク質の機能と多様性 について研究しています。また最近では、水産未利用資 源から生理活性物質を探索する研究も行っています。亀 井助教は、胚の観察や操作が容易なゼブラフィッシュを 用いて、発生時の酸素濃度や栄養状態などの環境要因の 変化が、その後の体成長の速度調節や多能性幹細胞の運 命決定に与える影響を調べています。そして私、関口は、

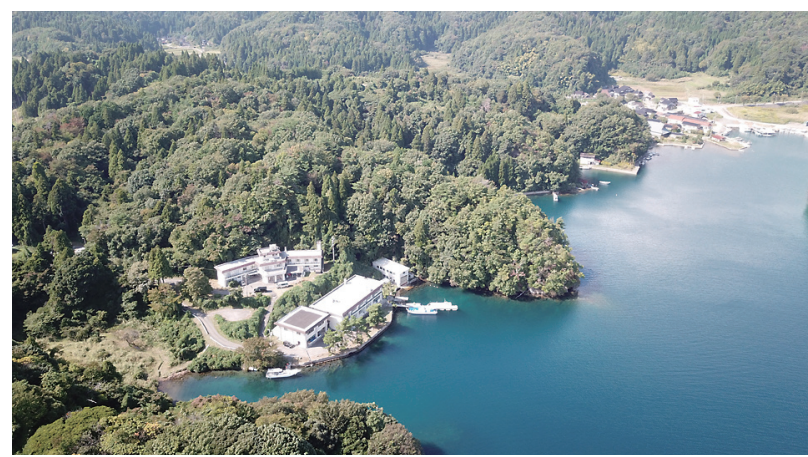

写真1 臨海実験施設全景

写真提供 : 金沢大学 塚脇真二教授

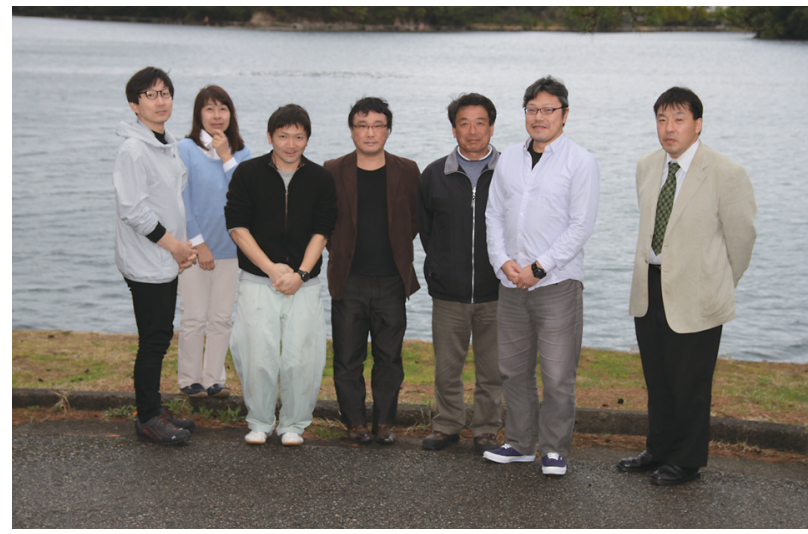

写真2 臨海実験施設スタッフ集合写真

左加亀井助教、曾良事務補佐員、小木曾主任技術職員、木 谷助教、又多技術補佐員、著者、鈴木教授

内分泌系・神経系の無脊椎動物から春椎動物への進化を 研究する目的で、原索動物 (ホヤやナメクジウオ) や円口 類 (ヌタウナギやヤツメウナギ) のホルモンペプチドの分 子機能や生理機能について研究しています。また環境污 染物質の影響を無脊椎動物や魚類で解析しています。

\section{臨海実験施設の教育活動}

当施設は、平成24年から文部科学省より教育関係共同 利用拠点に認定され、さらに平成29年度より平成33年度 まで「環日本海域の先端的環境・保全学に関する教育共同 利用拠点」に再認定されました。本年度は、高校生の実習 5件、金沢大学向けの実習2件に加え、11件の他大学実習、 2件の公開臨海実習が予定されています。公開臨海実習 は、全国の大学生が参加できる実習です。第1回目は、環 境保全をテーマにした実習で、アカテガニの生態やその 保全について実習します。第2回目は磯採集、シューノー ケリングなど野外実習と生化学の実験を同時に学ぶこと 
ができる実習です。本稿の読者の大学教員の方は講義等 で学生に、大学院生の方は後輩に、公開臨海実習を勧め ていただけると幸いです。詳しくはホームページ (http:// rinkai.w3.kanazawa-u.ac.jp/index.html）を参照ください。

\section{能登海洋教育施設 (仮称) について}

最後に、能登に開設される金沢大学の新施設について お知らせいたします。金沢大学では平成30年度より生命 理工学類 海洋生物資源コースが新設されました。環日本
海域環境研究センターの教員（鈴木、木谷、関口）は準専 任教員として、自然システム学類の教員 (亀井) は専任教 員として、本コースで教育活動を行います。本コースの 海洋資源に関する教育研究を行う新施設として、能登町 が所有する九十九グランドホテルを改修した「能登海洋教 育施設 (仮称)」が新設されます。本施設は臨海実験施設 の対岸に位置しており、相互に補完しながら能登の特性 を生かした海洋資源に関する教育と研究を実施する予定 です。

\section{東京医科歯科大学 教養部 生物学教室「服部研」}

松本 幸久 (東京医科歯科大学 教養部) E-mail: yukilas@tmd.ac.jp

\section{1. 東京医科歯科大学教養部について}

東京医科歯科大学は、その名のとおり東京都に本部を おく医学・歯学系の大学です。東京医科歯科大学には、 官立の歯学教育機関として日本で最初に設立された歯学 部があることは有名ですが、国立大学で唯一、教養部が 現存することはあまり知られていません。この教養部、 実は東京都にはありません。大学名に「東京」が入ってい ますが、お隣の千葉県にあります。「東京ディズニーラン ド」や「東京ドイツ村」と同じです。千葉県にありますが、 教養部の最寄りにある JRの市川駅は、東京駅から総武線 快速で約 30 分、東京医科歯科大学本部がある湯島の JR 御 茶ノ水駅から総武線で約25分とアクセスがよいです。こ のように東京都に近いですが教養部の周りには自然が多 くとてものどかです。季節になると教養部のすぐ近くに ある里見公園で桜やバラをめでたり江戸川で魚を釣った りできます。東京医科歯科大学の学生は医学科でも歯学 科でも、1年生のうちはのどかな教養部で教養教育をみっ ちり学びます。

\section{2. 研究室について}

教養部には自然科学系、人間科学系、外国語系の科目 があり、専属の教員は全員で24人しかいません。生物学 分野の教員 3 人 (服部淳彦教授、伊藤正則教授、松本幸久 助教)による研究室が通称「服部研」です。服部研の現在 (2018年3月) のメンバーは、教員 3 人の他、ポスドク 1 人、 大学院生 3 人、学部生 1 人の計 8 人です。このような小規模 ラボのためマンパワー不足は否めません。そのため、そ れぞれの教員は多くの他大学の研究室や企業との共同研 究を進めています。服部研の学生は毎週1度行っている ジャーナルクラブとプログレスレポートに参加すること が義務付けられていますが、それ以外は自分たちの裁量 で好きな時間に自由に実験をしたり動物の世話をしたり しています。

\section{3. 研究内容について}

研究については、3人の教員がそれぞれのテーマで研究

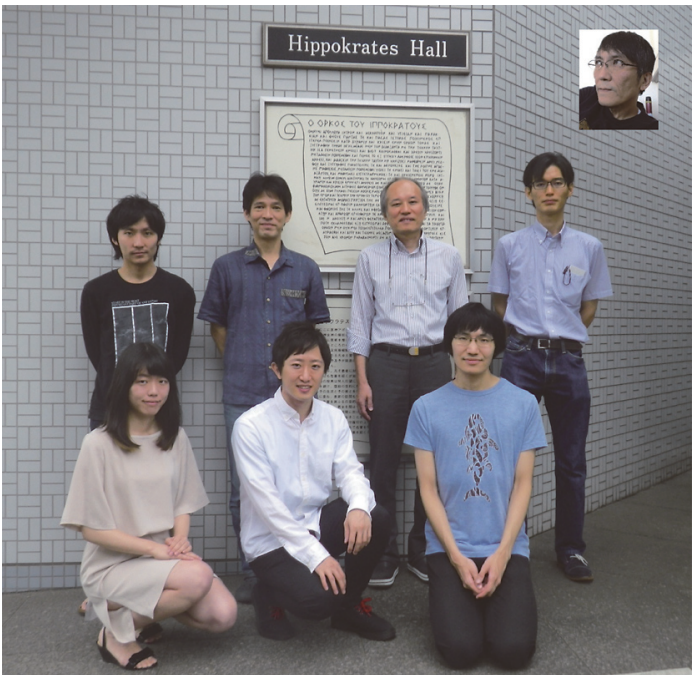

服部研のメンバー（教養部ヒポクラテスホール玄関にて） 後列右から2番目は服部教授、その左隣が松本。枠内は伊藤 教授。

を進めています。服部教授は、概日リズムの調節で知ら れているメラトニンやその脳内代謝産物である N-acetyl5-methoxykynuramine (AMK) の多様な機能（特に加齢と の関連で、骨、脳 (記憶)、代謝系への作用) について、 キンギョ、ウズラ、マウスなどの動物やヒトを対象にし て研究しています。現在は上智大学、金沢大学、新潟大学、 岡山大学、慶應義塾大学、同志社大学や複数の企業と共 同研究をしております。伊藤教授は、マウスやカエルな どを用いて(1)本能行動の脳制御機構と(2)卵母細胞の形成・ 成熟機構について調べています。これらの研究は聖マリ アンナ医科大学と長崎大学と共同で行っています。(1)で は性行動や育児行動を対象としています。(2)では始原生 殖細胞から卵祖細胞を経て卵母細胞一分化するメカニズ ムを明らかにすることが目標です。加えて、(1)と(2)を結 びつけた研究として、卵巣機能が行動の脳制御機構にお よぼす影響を解明しようと考えています。松本は、昆虫 のフタホシコオロギを材料に用いて、主に行動薬理手法 